\title{
Can environmental and social performance of Thai-listed companies create sustainable value?
}

\author{
Neungruthai Petcharat ${ }^{1 *} \&$ Phanthipa Srinammuang $^{2}$ \\ Faculty of Business and Management Studies, Al Khuwair Postal Code 133, Al Mabaila, Muscat, Oman \\ Faculty of Business, Kasetsart University, Jatujuk, Bankkhen, Bangkok, Thailand \\ *E-mail of the corresponding author: neungruthai@gulfcollege.edu.om
}

\begin{abstract}
This study explores an integrated reporting system of Thai-listed companies disclosing environmental and social performance in Thai context, and how integrated reports create sustainable value to stakeholders and users. A set of questionnaires is created to conduct Fifty-two of Thai companies listed in the Stock Exchange of Thailand. The samples are selected from five sectors including Transport, Machinery, Metal product, Electricity, Finance and banking, Food and beverage, Petroleum, and Telecommunication. Environmental and social performance indicators in annual reports and corporate social responsibility (CSR) are targeted for investigation. Correlation analysis methods are employed to test hypotheses. This study found that Thai-listed companies incorporated environmental and social performance in reporting system to satisfy information needs of stakeholders and users. Environmental and social performance integrated in the reports aims to create sustainable value in the eye of stakeholders and investors.
\end{abstract}

Keywords: Integrated reporting system, Environmental performance, Social performance, integrated reporting perspectives, sustainable value

DOI: $10.7176 /$ RJFA/10-10-23

Publication date:May $31^{\text {st }} 2019$

\section{Introduction}

Integrated reporting perspectives aim to incorporate financial and non-financial information - collective mind of those charged with governance and management performance in terms of economic, environment, and social well-being in annual reports (Deloitte, 2011). The effective communication in annual reports can support investments, stakeholders, public to understand how a company achieve its sustainability both immediately and in future (Deloitte, 2011). Thus, all accounting communication in annual reports comprises a holistic and integrated representation in all dimensions of long-term sustainability (Deloitte, 2011). In Thailand, however, integrated reporting is not been much of interest to the companies both service and non-service sectors. Whilst, little is known of actualities and possibilities of incorporating environmental and social information in a company's reports (Kuasirikun \& Sherer, 2004). Companies provide environmental and social data and/or statements in corporate social responsibility disclosures but rarely incorporated to annual reports (Kraisornsuthasinee, 2006). Environmental and social data is not accurately identified how a company meets the needs of corporate sustainability. Most companies are disclosing little emphasis on corporate social and environmental achievement (Kuasirikun \& Sherer, 2004) while tending to primarily disclose more information on social aspects (Prayukvong \& Olsen, 2014). This results in environmental and social data in financial statements become more difficult to the financial analysts when estimating potential returns and investment risks (Eccles, Herz, Keegan, \& Phillips, 2001). KPMG (2012) claimed that integrated Reporting can help firms explain their operational performance regarding adding shareholder value. Recently, GRI and International Integrated Reporting Council (IIRC) have agreed that corporate reporting needs to be shown the link between a company's financial statement and its environmental and social performance (Deloitte, 2011; The IIRC Organization, 2013). Integrated Reporting creates a better opportunity for a company to support investors' and stakeholders' interests in embracing a sustainable future (Deloitte, 2011; The IIRC Organization, 2013). Thus, this study examines environmental and social performance integrated in annual reports for information needs of stakeholders. Environmental and social performance in integrated reporting system of Thai companies for sustainable value creation in the eye of stakeholders is explored.

\section{Prior literature and theoretical perspectives}

Over decades, Thailand has been known as one of the most attractive countries in Southeast Asia due to cheaper labour and rich in natural resources and transforming an agricultural-based society to the manufacturing economy (Kuasirikun \& Sherer, 2004). Integrated reporting in Thai context however has not much widely known. The development of environmental and social performance along with eco-efficiency in Thai context could go a long way to improving accounting's approach to these issues. Companies have paid less intention to incorporate neither environmental nor social data in their annual reports. As a result, international market has been concerned about social well-being and environmental awareness of Thai companies for decades (Kuasirikun \& Sherer, 2004). Companies have been required to ensure that they have met international and social environmental standards (Thapanachai, 2000; Tungrhapheephakorn, 2001cited in Kuasirikun and Sherer (2004)). They are suggested that environmental and social data should be precisely reported in a company's financial statement that associated with the information in voluntary disclosures. Based on environmental and social indicators of international measures such as ISO 14000 for Environmental Management and ISO 18000 for Health and Safety at Work Management, international measures are introduced as a guidelines to help reporting employee-friendly and environmentally aware in order to ensure that business practices meet environmental and social development requirements (Kuasirikun \& Sherer, 2004).

Integrated reporting perspectives in Thai context however have not been much of interest to Thai companies while the demands place on the environmental and social reporting system that adds shareholder value in marketplace (Ratanajongkol, Davey, \& Low, 2006). Thai practices for integrating environmental and social data in a company's reports need to be explored its potential to enable communication between a company and its stakeholders (Kuasirikun \& Sherer 2004). In addition, little research has been undertaken on the linkage between environmental and social information in financial/annual reports and corporate social responsibility (CSR) 
disclosures. Although some previous studies examined environmental and social aspects in Thai context, an integration of environmental and social accounting in a company's financial report has not been widely explored in the literature, particularly in relation to the linkage between information in annual reports and CSR disclosure (Kuasirikun, 2005; Kuasirikun \& Sherer, 2004; Suthisak Kraisornsuthasinee \& Swierczek, 2009).

Environmental and social performance reporting in Thai context however needed to be further developed to integrating accounting in a company's report and voluntary disclosure basis. Meanwhile cost information of environmental and social factors needs to be accurately identified and measured, especially the factors of determining ways in which companies disclose their environmental and social performance to the stakeholders and public (Kraisornsuthasinee, 2006). An integration of environmental and social data in a company's reports of Thai companies are explored fall short of companies' potential to enable accounting communication in Thai context (Kuasirikun \& Sherer, 2004; Thawornwong, 2011). Kuasirikun (2005) suggested that future research should explore how Thai accounting profession and relevant governmental agencies might be engaged in exploring and developing a more enabling accounting practice. This would make the changes that accommodates and provides balanced representation in both numerical and narrative forms. This would be the ways in which the further development of environmental and social accounting concepts can be given impetus for environmental and social aspects to the Thai context (Kuasirikun, 2005).

Environmental and social performance is reported to address increased concerns of stakeholders and public while creating companies images of environment-friendly organizations in marketplace (Connelly \& Piman Limpaphayom, 2004; Kittiya Yongvanich \& James Guthrie, 2006). Thus, it is a matter for concern that providing more effective accounting framework can help recognize, identify, and measure environmental data. By adopting such a framework, it would help support to meet the concerns of stakeholders in incorporating environmental costs into sustainability disclosures (Kuasirikun, 2005; The Sigma Project, 2003; UNDSD, 2001). Environmental and social data should be consistently integrated in annual reports for sustainable value creation. In relation to this, environmental and social performance of Thai companies should be accurately reported in both mandatory and voluntary disclosures for building sustainable value in the eye of stakeholders, as well as maximizing shareholder wealth in marketplace.

Thus, with a focus on integrated reporting perspectives in Thai context, an integration of environmental and social performance in a company's reports is the main aim of this study. This is to describe and evaluate how environmental and social information incorporate in annual reports that linked with the information in the for sustainable value creation of Thai companies. Environmental and social data fully incorporated in a company's reports enhance investment decision in relation to cost savings - resources efficiency, waste minimization, and pollution abatement. Environmental and social data in a company's reports that meet integrated reporting initiatives create eco-efficiency along with environmental and social performance. Environmental and social performance fully incorporated in integrated reporting systems enables to satisfy information needs of stakeholders and users. The information of environmental data and social performance in the integrated reports of Thai-listed companies create sustainable value in the eye of stakeholders and users.

\section{Research questions and hypotheses}

An investigation of this study aims to bring out the appropriate ways to integrate environmental and social data in a company's reports - annual reports. Environmental and social data provided in annual reports should be consistent with the information creating sustainable value when addressing interests of investors and stakeholders or public. Thai companies are required to incorporate environmental and social performance in annual reports and voluntary disclosures (Thapanachai, 2000; Tungrhapheephakorn, 2001cited in Kuasirikun and Sherer (2004)) to ensure their sustainability. Environmental and social data needs to be provided based on environmental and social indicators of international measures (Kuasirikun \& Sherer, 2004). Environmental and social data in annual reports enable to satisfy information needs of stakeholders and investors or public. Research questions and its hypothesis are posed to fill the key gaps identified in the literature.

RQ: To what extent does an integration of environmental and social performance in integrated reporting of Thai-listed companies create sustainable value in the eye of stakeholders and users?

H1. Environmental and social information in integrated reports of Thai-listed companies satisfies information needs of stakeholders and users

As little is known about integrated reporting perspectives in Thai context, Thai practices for an integration of environmental and social data in a company's reports should be introduced to enable communication between a company and its stakeholders (Kuasirikun \& Sherer, 2004). Thai companies should report environmental and social information in annual reports for sustainable value creation in the eye of stakeholders. This would support stakeholders' and public's interests effectively rather than creating companies' images of environmentally and socially aware organizations (Chambers, Chapple, Moon, \& Sullivan, 2003; Kuasirikun \& Sherer, 2004). This study also investigates environmental and social information incorporated in annual reports that meets the needs of integrated reporting perspectives. Environmental and social data in annual reports can potentially address stakeholders' and public's interests (Deloitte, 2011). An integration of environmental performance in a company's reports can be supported investment decisions of its stakeholders significantly (Freeman, 1994). Accurate environmental and social information is one of effective investment decision tools for business decision makers those seeking balanced information set of economic, environmental, and social performance to achieve sustainability targets (Cormier, Gordon, \& Magnan, 2004; Lamberton, 2005; Schwarzkopf, 2006). Thus, Hypothesis 2 is posted.

H2: Environmental and social performance in integrated reporting systems of Thai-listed companies creates sustainable value in the eye of stakeholders and users.

Environmental and social data in Thai context should be reported in the form of a corporate social responsibility to create image and reputation as environmentally and socially aware organizations. As Thai companies have defined corporate sustainability reports as a business strategy, this could help create long-term economic development while building positive reputation in the eye of stakeholders and marketplace (Nijkamp \& Vreeker, 2000; Thawornwong, 2011). This results in companies are having less intention to move towards integrated reporting perspectives. Thai companies have also been found as primarily focusing on human resources, thus providing "declarative" good news disclosures, rather than integrating information in annual reports and/or voluntary disclosures (Ratanajongkol et al., 2006). 


\section{Research methodology}

A sampling group of fifty two of Thai-listed companies was selected from the seven sectors including Transport (14), Machinery (12), Metal product (7), Electricity (5), Finance and banking (5), Food and beverage (3), Petroleum (3), and Telecommunication (3) using purposive sampling methods. A set of survey was created to investigate environmental and social information integrated in annual reports and corporate social responsibility (CSR) disclosures, 2013 and 2015. Evidence was mainly collected through a review of documents (annual reports and CSR disclosures) provided on the website of the Stock Exchange of Thailand. Environmental and social performance indicators relating to volume of materials, energy, waters, and wastes, expenditures and/or activities provided to manage environmental and social issues were targeted. Correlation analysis was employed to test $\mathbf{H} \mathbf{1}$ and H2, as it is a measure of the statistical relationship between two comparable variances (Hair, Anderson, Tatham, \& Black, 1998).

\section{Findings}

\subsection{Analysis results}

Table 1 illustrates that there is a significant relationship between environmental and social information in integrated reports of Thailisted companies and satisfaction of stakeholders and users. There is a significance relationship between stakeholder satisfaction and environmental performance in integrated reporting of Thai-listed companies $(\mathrm{p}=.000$, at 0.01 alpha level $)$ and social performance in integrated reporting of Thai-listed companies $(\mathrm{p}=.000$, at 0.01 alpha level) (Table1). This can be indicated that environmental and social performance in integrated reporting of Thai-listed was satisfied information needs of stakeholders and uses. Thus, H1, Environmental and social information in integrated reports of Thai-listed companies satisfies information needs of stakeholders and user is supported.

Table 1: Test of correlation between environmental and social performance in integrated reporting

\begin{tabular}{llrrr} 
& \multicolumn{3}{c}{ H1 } \\
\hline & & $\begin{array}{l}\text { Stakeholder } \\
\text { satisfaction }\end{array}$ & $\begin{array}{c}\text { Environmental } \\
\text { performance }\end{array}$ & Social performance \\
\hline Stakeholder satisfaction & Pearson Correlation & 1 & $.577^{* *}$ & $.485^{* *}$ \\
& Sig. (2-tailed) & 52 & .000 & .000 \\
& $\mathrm{~N}$ & 52 & 52 \\
Environmental and social & Pearson Correlation & $.577^{* *}$ & 1 & $.577^{* *}$ \\
performance & Sig. (2-tailed) & .000 & 52 & .000 \\
& $\mathrm{~N}$ & 52 & $.577^{* *}$ & 52 \\
Social performance & Pearson Correlation & $.485^{* *}$ & .000 & 1 \\
& Sig. (2-tailed) & .000 & 52 & 52 \\
& $\mathrm{~N}$ & 52 & &
\end{tabular}

**. Correlation is significant at the 0.01 level (2-tailed).

The table 2 also shows that environmental data and social performance in integrated reporting systems of Thai-listed companies create sustainable value in the eye of stakeholders and users. There is a significant relationship between environmental and social performance of Thai-listed companies in the reports and information needs of stakeholders ( $\mathrm{p}=.000$, at 0.01 alpha level). And there is a significance relationship between environmental and social performance of Thai-listed companies and sustainable value create in the eye of stakeholders and uses ( $\mathrm{p}=.000$, at 0.01 alpha level) (Table2). This can be indicated that environmental and social performance in integrated reporting of Thai-listed enables to create sustainable values in the eye of stakeholders and users. Thus, $\mathrm{H} 2$, Environmental and social performance in integrated reporting systems of Thai-listed companies creates sustainable value in the eye of stakeholders and users. is answered.

Table 2: The correlation between environmental and social performance in integrated reporting

H2

\begin{tabular}{llrrr}
\hline & & $\begin{array}{c}\text { Environmental } \\
\text { performance }\end{array}$ & $\begin{array}{r}\text { social Information need } \\
\text { stakeholder }\end{array}$ & Sustainable value \\
\hline Environmental and social Pearson Correlation & & 1 & $.997^{* *}$ & $.610^{* *}$ \\
performance & Sig. (2-tailed) & & .000 & .000 \\
& $\mathrm{~N}$ & 52 & 52 & 52 \\
Information need of & Pearson Correlation & $.997^{* *}$ & 1 & $.633^{* *}$ \\
stakeholders & Sig. (2-tailed) & .000 & & .000 \\
& $\mathrm{~N}$ & 52 & 52 & 52 \\
Sustainable value & Pearson Correlation & $.610^{* *}$ & $.633^{* *}$ & 1 \\
& Sig. (2-tailed) & .000 & .000 & 52 \\
& $\mathrm{~N}$ & 52 & 52 & 5 \\
\hline
\end{tabular}

**. Correlation is significant at the 0.01 level (2-tailed). 


\subsection{Discussion of the results}

Environmental and social information in integrated reports of Thai-listed companies satisfies information needs of stakeholders and user

As little is known about integrated reporting perspectives in Thailand, environmental and social reporting has become a mainstream driven by the potential shareholder value for decades. Environmental and social information in a company's report can increase the efficiency with which stakeholders use financial information for their investment decision (Kuasirikun \& Sherer, 2004). Environmental and social performance of Thai-listed companies (a sampling group) incorporated in integrated reporting system in Thai context enabled to satisfy information needs of stakeholders and users. Environmental and social reporting has become a mainstream driven by the potential shareholder value for decades. Environmental and social information in a company's report can increase the efficiency with which stakeholders use financial information for their investment decision (Kuasirikun \& Sherer, 2004). According to the results of the study, listed companies from service and non-service sectors reported environmental and social information in annual reports to satisfy information needs of stakeholders. This results in stakeholders are more interested in understanding the approach and performance of companies in managing the sustainability aspects and activities, as well as creating potential for value creation (Ratanajongkol et al., 2006; K. Yongvanich \& J. Guthrie, 2006). Companies from petroleum sectors paid most attention to integrate environmental data in both annual reports and CSR disclosures. Companies incorporated total volume of direct and indirect materials and energy, percentage of recycled materials and energy saved, energy reduction program, total usage of water, and percentage of water recycled. It also included total number of direct GHG emission and other indirect GHG emission in tonnes of $\mathrm{CO}_{2}$ equivalent, $\mathrm{GHG}$ emissions reductions programs/methods or production materials used, total volume of wastes, total volume of internationally transported, percentage of reused products and recycled packaging materials, initiatives to reduce environmental impacts and transporting products, total expenditures of environmental protection, other GHG Emissions - Methane (CH4), Per-fluorocarbons (PFC), Nitrous oxide (N2O), Hydro-fluorocarbons (HFC), and/or Sulfur-hexafluoride (SF6). In addition, petroleum sectors most likely integrated social information in relation to labour practices and working conditions - employees' benefits, education, training, and counselling, health and safety, as well as community development where companies operate. Social information also included social development program, percentage of employees trained, and product responsibility including life cycle of product usages, product information, customer satisfaction, laws and regulations concerning the provisions and use of products.

Environmental and social performance in integrated reporting systems of Thai-listed companies creates sustainable value in the eye of stakeholders and users

Since Thai companies have been required to ensure that they have met international and social environmental standards (Thapanachai, 2000; Tungrhapheephakorn, 2001 cited in Kuasirikun and Sherer (2004)). Thai companies are aiming to implement and demonstrate greater concerns and responsibility for environmental and social problems (Ratanajongkol et al., 2006). Environmental and social information has been attempted to incorporate in annual reports and voluntary disclosures to add shareholder value in the eye of stakeholders and public (Prayukvong \& Olsen, 2014; Suthisak Kraisornsuthasinee \& Swierczek, 2009). With this greater business opportunity, this study examined the environmental and social data integrated in annual reports CSR disclosures of listed companies in Thailand for sustainable value creation in the eye of stakeholders and users. This study found that environmental and social information integrated in the reports has fully represented overall corporate sustainability to stakeholders and public. This study found that companies indicated their intentions to incorporate environmental and social information in annual reports and CSR disclosure in future for value creation. Companies reported total volume of direct and indirect materials and energy used in production process, as well as energy saved, waste minimization, and water efficiency, thus establishing ecosystem and providing transparency into the environmental aspects. Meanwhile, social information was integrated in annual reports and CSR disclosures to support information needs of stakeholders. Companies incorporated employees' benefits, community development, product responsibility, and quality of life of employees in future reporting. This included reducing negative impacts on local community where companies operate, and enhancing social well-being as a whole.

As a consequence, the results of the hypotheses testing provide a useful starting point to underpin a comprehensive conceptual model applying integrated reporting systems disclosing environmental and social performance in annual reports of voluntary disclosures. Environmental and social data should be reported appropriately both internally and externally and that comprise a holistic and integrated representation to enhance long-term environmental and social sustainability for value creation (Deloitte, 2011). This can build greater relationship between a company and its stakeholders (Cormier et al., 2004; Schwarzkopf, 2006). An effective integrated reporting represents organizations' ability to create and sustain corporate value based on economic, social, and environmental systems (Deloitte, 2011; The IIRC Organization, 2013). Environmental and social data in integrated reporting (The IIRC Organization, 2013) represents the creation of corporate sustainability effectively (Deloitte, 2011) to add shareholder value in the eye of stakeholders and marketplace. Environmental and social data integrated in annual report is mainly involved with environmental efficiency, consumers, investors, and civil society which it is increasingly demonstrated that they value the social responsibility of corporations. An integration of environmental and social data in a company' report can lead a more responsible management practice and deal with public concerns. This helps increase in the visibility of environmental and social data in a mandatory disclosure and bring up accounting information to the same level with financial reports (Deloitte, 2011). And it can help companies to create better relationship between non-financial and financial measure to contribute to the long-profitability of sustainable companies in Thailand and global markets. Environmental and social performance was identified from the results of the study that comprise a holistic and integrated representation shown in Table 3. 
Table 3: Environmental and social performance in integrated reporting system

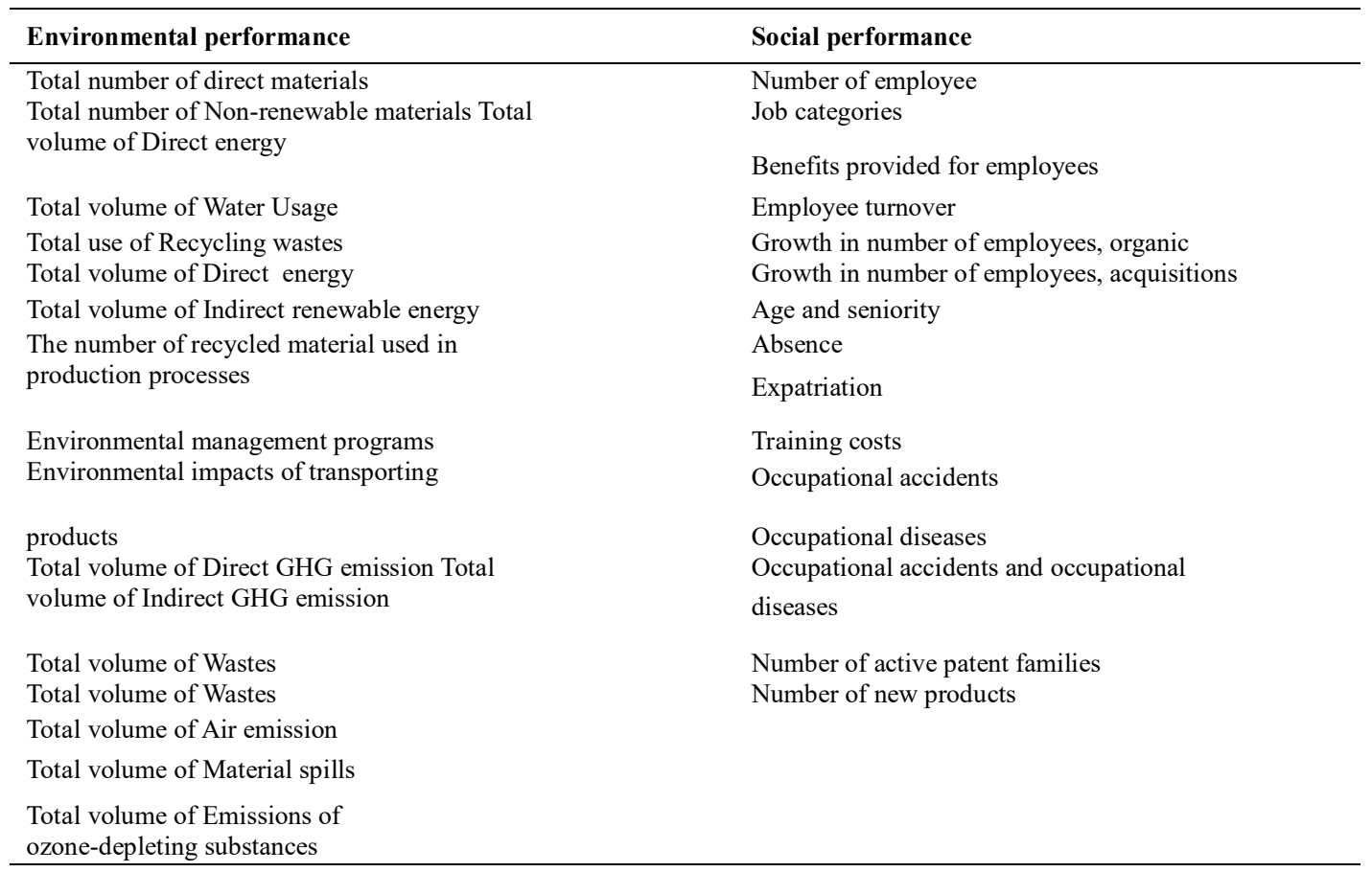

\section{Conclusion and policy implications}

Based on the results of the study, environmental and social performance integrated in reporting systems of Thai-listed companies (a sampling group) aims to satisfy information needs of stakeholders and users. Thai-listed companies incorporate environmental and social information in the reports to build strong relationships with their stakeholders. Environmental and social data in integrated reporting (The IIRC Organization, 2013) represents the creation of corporate sustainability effectively (Deloitte, 2011) to add shareholder value in the eye of stakeholders and marketplace. Environmental and social data integrated in annual report is mainly involved with environmental efficiency, consumers, investors, and civil society which it is increasingly demonstrated that they value the social responsibility of corporations. Environmental data and social performance in integrated reporting systems of Thai-listed companies enables to create sustainable value in the eye of stakeholders and users. An integration of environmental and social data in a company' report can lead a more responsible management practice and deal with public concerns. This helps increase in the visibility of environmental and social data in a mandatory disclosure and bring up accounting information to the same level with financial reports (Deloitte, 2011).

The results of the study contribute to the literature as the first attempt that aims to integrate environmental and social data in a company's reports. Regarding to the external stakeholders, environmental liabilities can be acknowledged in financial statements or annual reports as they must be reasonably reported to support stakeholders' and public's demands (Panyarachun, 2003). Integrated reporting perspectives in Thai context enable more effective decision-making and improve the information to address the demands of stakeholders and investors when investment decision needs to be made (Deloitte, 2011; KPMG, 2012; The IIRC Organization, 2013). The SFRS integrates environmental and social data in a company's disclosures to create more sustainable firms both immediately and in future (Suthisak Kraisornsuthasinee \& Swierczek, 2009).

The results of the study contributes to the practices that integrated reporting systems helps companies in reporting more effective data on environment and social performance. Environmental and social data identified from the results can be of benefits to financial accountants to incorporate environmental and social data that represent environmental and social management policy and how a company achieves its corporate sustainability. Environmental and social information integrated in annual reports enables to address stakeholders' and public's interests. As only a small group of Thai companies that has been recognized as integrated reporting leaders, the results of the study would enlarge a number of Thai companies to integrate transparent data in their reports. This helps a sustainable company creates the linkage between environmental and social data in a company's reports to business sustainability policy and strategy can reinforce role in value creation.

There are some limitations to the study that need to be mentioned including a sampling group and sample size due to only few companies that have fully interested in integrated reporting systems. Future research should extend beyond the sample group to further in corporate accurate environmental and social data in corporate social responsibility reports. Based on the survey, integrated reporting in Thai context appeared less attention from companies in Thailand. Future research should investigate the focuses on both environmental and social performance in a company's reports using in-depth interview with board directors and or corporate sustainability managers to enrich environmental and social information. A sustainability financial reporting system should be further explored to fully develop a comprehensive system for more effective integrated reporting system in Thai context. 


\section{Acknowledgement:}

We would like to thank fifty-two listed companies in Thailand in providing annual reports and corporate social responsibility (CSR) disclosures (2012-2015) for research and study. The results of the study would benefit to policy makers and integrated reporters in Thailand.

\section{Reference}

Chambers, E., Chapple, W., Moon, J. and Sullivan, M. (2003), "CSR in Asia: A seven country study of CSR website reporting", in Matten, D. (Ed.). International Centre for Corporate Social Responsibility, Nottingham University Business School, Nottingham University, Nottingham.

Connelly, T. J. and Piman Limpaphayom. (2004), "Environmental Reporting and Firm Performance: Evidence from Thailand", Journal of Corporate Citizenship, Vol. 13 No. 0, pp. 137-149.

Cormier, D., Gordon, I. M. and Magnan, M. (2004), "Corporate Environmental Disclosure: Contrasting Management's Perceptions with Reality", Journal of Business Ethics, Vol. 49, pp. 143-165.

Deloitte. (2011), "Integrated Reporting Navigating your way to a truly Integrating Report", in. Deloitte Development LLC, Johannesburg.

Eccles, R. G., Herz, R. H., Keegan, E. M. and Phillips, D. M. H. (2001), The Value Reporting Revolution, Wiley, New York.

Freeman, E. R. (1994), "Stakeholder Theory of the Modern Corporation", in General issues in Business Ethics, pp. 38-48.

Hair, J. F., Anderson, R. E., Tatham, R. L. and Black, W. C. (1998), Multivariate Data Analysis, Pearson Education New Delhi.

KPMG. (2012), "Integrated Reporting Performance insight through: Better Business Reporting", available at: htt://www/kpmg.com/integratedreporting (accessed 30 November 2012 2012)

Kraisornsuthasinee, S. (2006), "Interpretations of CSR in Thai Companies", Journal of corporate citizenship, Vol. 22 No. 1, pp. 5365.

Kuasirikun, N. (2005), "Attitudes to the development and implementation of social and environmental accounting in Thailand", Critical Perspectives on Accounting, Vol. 16 No. 8, pp. 1035-1057.

Kuasirikun, N. and Sherer, M. (2004), "Corporate social accounting disclosure in Thailand", Accounting, Auditing \& Accountability Journal, Vol. 17 No. 4, pp. 629-660.

Lamberton, G. (2005), "Sustainability accounting—a brief history and conceptual framework", Accounting Forum, Vol. 7 No. 26, pp. 13-14.

Nijkamp, P. and Vreeker, R. (2000), "Sustainability assessment of development scenarios: methodology and application to Thailand", Ecological Economics, Vol. 33 No. 1, pp. 7-27.

Panyarachun, A. (2003), "The Necessity of CSR", Bangkok Post, 20 September 2003. pp. 11.

Prayukvong, P. and Olsen, M. (2014), "Research on the CSR Development in Thailand", in. The Network of NGO and Business Partnership for Sustainable Development (Thailand): UN Volunteers.

Ratanajongkol, S., Davey, H. and Low, M. (2006), "Corporate social reporting in Thailand: The news is all good and increasing", Qualitative Research in Accounting \& Management, Vol. 3 No. 1, pp. 67-83.

Schwarzkopf, D. L. (2006), "Stakeholder Perspectives and Business Risk Perception", Journal of Business Ethics, Vol. 64, pp. 327342.

Suthisak Kraisornsuthasinee and Swierczek. (2009), "Doing well by doing good in Thailand", Social Responsibility Journal, Vol. 5 No. 4 , pp. 550 - 565.

Thapanachai, S. (2000), "Textile and garment firms urged to improve standards: Western customers ask more questions about worker rights", Bangkok Post. pp. 3.

Thawornwong, S. (2011), "A survey of corporate sustainability of MIT ", in. Corporate Social Responsbility Institute (CRSI), Bangkok.

The IIRC Organization. (2013), "GRI and IIRC deepen cooperation to shape the future of corporate reporting ", available at: http://www.theiirc.org/category/press/iirc-key-press-releases/ (accessed 1 March 20132013 ).

The Sigma Project. (2003), "The Sigma Guidelines - Toolkit: Sustainability Accounting Guide", in. The UK Department of Trade and Industry (DTI), London.

Tungrhapheephakorn, S. (2001), "Management in Thai factories and university research projects on dangerous material", in Phujudkarnraiwan, Bangkok, pp. 3.

UNDSD. (2001), "Environmental Management Accounting Procedures and Principles", in. United Nations Division for Sustainable Development (UNDSD), New York, pp. 8.

Yongvanich, K. and Guthrie, J. (2006), "An extended performance reporting framework for social and environmental accounting", Business Strategy and the Environment, Vol. 15 No. 5, pp. 309-321.

Yongvanich, K. and Guthrie, J. (2006), "An extended performance reporting framework for social and environmental accounting", Journal of Business Strategy and the Environment, Vol. 15 No. 5, pp. 309-321. 